\title{
The effects of menstrual and menopausal factors on bone mineral content in healthy Polish women
}

\author{
Alicja Szklarska, Ewa Jankowska, Monika Łopuszańska \\ Institute of Anthropology, Polish Academy of Sciences, Kuźnicza 35, \\ 50-951 Wrocław, Poland; E-mail: alicja.szklarska@antro.pan.wroc.pl
}

\begin{abstract}
The aims of this study were the following: (1) An evaluation of which factor, aging itself or the occurrence of menopause, revealed a more detrimental effect on bone mineral content (BMC) of healthy women; (2) An assessment of influence of other factors (the menarcheal age, the total number of reproductive years and the length of the period after menopause) on BMC. Our sample material comprised a group of 928 healthy females (715 pre- and 213 postmenopausal), aged 20-62. BMC at the ultra-distal radius was assessed by $\mathrm{pQCT}$. BMC differences between particular groups were tested using a two-way ANOVA. The menopause was related to BMC decline and the impact of menopausal hormonal alterations was much stronger than that of chronological age. Among postmenopausal women, the total number of reproductive years was not an independent predictor of better bone status. In premenopausal women the beneficial effect of earlier menarche on bone tissue is maintained.
\end{abstract}

KEY WORDS BMC, osteoporosis, menarcheal age, age at menopause, female aging

Prz. Antropol. - Anthropol. Rev. (2002), vol. 65, pp. 43-56, Figs. 6, Tables 4. ISBN 838696-80-6, ISSN 0033-2003

\section{Introduction}

The physiological hormonal activity of the ovaries is essential and indispensable for the acquisition of optimal peak bone mass in women and subsequently is requisite for the maintenance of proper values of bone mineral density (BMD) during the whole female lifetime. It was almost 60 years ago when Fuller Albright found a relationship between estrogens and calcium metabolism in women; according to his observation estrogen supplementation to postmenopausal women significantly reduced the renal elimination of calcium [ALBRIGHT 1941]. The following years saw considerable development towards improved knowledge of the importance of estrogen for female health, as well as great progress in understanding the molecular basis of the effects of estrogen 
on female bone tissue. The generally known phenomenon of accelerated bone loss in women after the cessation of sex-steroids production by the ovaries is a clinical manifestation of the indispensable role played by estrogens in homeostasis of the female skeleton.

Bone tissue normally undergoes senile involution, similar to other human tissues and organs, and hence reduction of bone mass with age is one of the signs of normal aging. At more advanced stages, such decline may finally result in osteopenia and osteoporosis, a condition in which the resistance of bones to fracture becomes very much reduced. It is noteworthy that in 1950 an average female lifespan was 47.8 , by 2000 it had been estimated to rise to 67.8 , and by 2050 to increase to 79.3 years [The Weimar Initiative 1998]. Considering the world-wide phenomenon of the increasing average human lifespan, particularly in modern industrial societies, age-related decline in BMD with subsequent osteoporotic fractures is of obvious medical, psychological and socio-economic importance [JOHNELL 1997, LIPPUNER et al. 1997, WALKER-BONE et al. 1998].

Nowadays there is no univocally and comprehensively (in respect of scientific analyses) proven view as to factors that have a significant and conclusive impact on the status of female bone tissue, particularly during the circum-menopausal period: the chronological age (as an equivalent of senile processes modifying bone structure of elderly women) or the fact of menopause (accompanied by the physiologic shortage of estrogens influencing on homeostasis of female bone tissue). The first aim of this study is the determination of whether ageing itself, or the occurrence of menopause, is more detrimental to the bone mineral content (BMC) of healthy women, inhabitants of Wrocław, Lower Silesia, Poland.

Although bone deterioration around the time of menopause is driven mainly by estrogen deficiency, the significance of estrogens in acquisition and preservation of skeletal mass at earlier stages of life is less well understood. The greatest acquisition of BMD occurs during female adolescence and early adulthood and, undoubtedly, the quantity of bone mass accrued at that time may significantly result in bone status in later life [MCKAY et al. 1998]. Additionally, according to some authors, the delayed menarche is considered an important risk factor for development of osteoporosis [MATKOVIC et al. 1997].

In a population of healthy women there is a normal variability of other factors resulting from reproductive history, such as: the menarcheal age, the total number of reproductive years and the period after menopause. Results from previous studies concerning the relationships between various reproductive factors and bone mineral density have been conflicting [MCKAY et al. 1998, BONOFIGLIO et al. 1999, FoX et al. 1993, KRITZSILVERSTEIN and BARRETT-CONNOR 1993, Young et al. 1995]. Therefore, the second aim of this study is to evaluate the effects of other factors resulting from the reproductive history (as mentioned above) on BMC of adult healthy women in an urban population in Poland. It should be emphasised that to the extent of our knowledge - no analogous data on female bone mineral status and its relation to reproductive history have so far been collected anywhere in Eastern Europe. 


\section{Materials and methods}

Our material comprises 928 females, aged 20-62 years, healthy and occupationally active inhabitants of the city of Wrocław, Lower Silesia, Poland. The Polish population is and has since 1940 been ethnically highly homogenous, hence whatever differences in bone density are observed probably reflect the impact of the physical and/or social environment, and are very unlikely to be due to any inter-generation shifts in the genetic composition of the studied population [GRONKIEWICZ 2001]. The examined female data constitutes a representative sample of a Polish large-city population with typical socio-demographic features. Thus, the phenomena revealed within this sample may be generalised to include all urban female Polish populations. All subjects were medically examined during 1997-1998 at The Silesian Centre for Preventive Medicine DOLMED in Wrocław during the course of routine health screening surveys since the early 1980s, among employees in various local institutions of state, municipality and the private sector.

From the present analysis was excluded all persons with chronic diseases known to influence calcium metabolism (such as: hyperthyroidism, hyperparathyroidism, neoplasia, e.g., myeloma, liver disease, chronic renal failure, gastric surgery), as well as those taking drugs that may affect bone metabolism (corticosteroids, hormones of any kind, antiepileptic drugs, diuretics, cytostatics, antidiabetic drugs, antihypertensive drugs). Furthermore, women with estrogen supplementation were excluded from this study.
In all subjects trabecular, cortical and total bone mineral content at the ultradistal radius of the nondominant hand were assessed by peripheral Quantitative Computed Tomography (pQCT), using the XCT Stratec 960 apparatus. The ultra-distal scan location in pQCT is centred at $4 \%$ of the forearm length proximal to the radial endplate an anterior-posterior scout view [AUGAT et al. 1998]. All measurements of density were made using the scanner connected with the computer system with an X-ray tube $(38,5 \mathrm{KeV})$ as a source of radiation. Trabecular, cortical and total BMC were assessed separately and expressed in $\mathrm{mg}$ of hydroxyapatite per $\mathrm{cm}^{3}$. The peripheral location of the human forearm, with its relatively small amount of surrounding soft tissues, improves the accuracy of the precision of bone mass measurement and has made this site an early choice for the assessment of a subject's bone mineral status [AUGAT et al. 1998]. The method measures bone density with a high degree of precision [GORDON et al. 1996]. It is worthy of note that cortical bone mineral density at the distal radius is a good predictor of the vertebral fracture status and a reliable indicator of the general agerelated skeletal deterioration [GÄRDSELL et al. 1993, GRAMPP et al. 1995]. Therefore, BMC at the distal radius may be useful in the diagnosis of osteopenia and osteoporosis [HASEGAWA et al. 1997].

The age (during BMC measurement), the menarcheal age and the age at menopause of all examined subjects were obtained by means of a questionnaire. A valid premenopausal state was judged to be the presence of a normal and regular menstrual cycle and the absence 
of menopausal symptoms in each case. A valid postmenopausal state was judged - according to the WHO definition - to be the absence of menstrual bleeding for at least 12 months. In all postmenopausal women included in this study (213 subjects) natural menopause was stated. Additionally, for each postmenopausal woman a total number of reproductive years (age at menopause minus age at menarche) and the period that passed after menopause until the time of BMC measurement (age minus age at menopause) were calculated.

All densitometric parameters of the examined women were tested for skewness but none was found; therefore arithmetic means were used for their description in particular age categories. Among all examined subjects were 715 premenopausal women (aged 20-53) and 213 postmenopausal women (aged 41$62)$. The range of variation of the age at menarche and age at menopause were, respectively: 9-18 years (mean age at menarche $-13.5 \mathrm{yrs}$ ) and $41-53$ years (mean age at menopause - 48.3 yrs). The range of variation of the total number of reproductive years and the period after menopause (calculated only in postmenopausal women; mean years after menopause - 5.1 yrs) were, respectively: 21-44 years and 1-17 years.

In order to calculate the mean values of trabecular, cortical and total BMC (separately in pre- and postmenopausal women) all subjects were divided into fourteen, basically 3-year age, categories (20-23, 24-26 ... 57-59, 60-62). Differences in particular BMC between two groups of women (pre- versus postmenopausal) in appropriate age categories were tested using a two-way ANOVA. In order to calculate the mean values of trabecular, cortical and total $\mathrm{BMC}$ with regard to the menarcheal age all subjects were divided into seven, basically 6-year age, categories (20-26... 57-62). Differences in particular BMC between subjects of early (to $12 \mathrm{yrs}$ ), average (13-14 yrs) and delayed (15 and more yrs) menarche in appropriate age categories were tested using a two-way ANOVA. The analyses were made separately in 2 groups: pre- and postmenopausal women. The significance of differences in particular BMC with regard to the total number of reproductive years and the period after menopause was evaluated using a two-way ANOVA (only in postmenopausal women). The categories of the total number of reproductive years were the following: 21-31, 32-36, 37-44 years. The categories of the period after menopause were the following: 1-2, 3-6, 7 and more years.

\section{Results}

Figures 1, 2 and 3 present the mean values of trabecular, cortical and total BMC of healthy Polish women, evaluated in particular 3-year age categories, separately in pre- and postmenopausal females. The curves of BMC decline with age and reveal large differences in BMC between pre- and postmenopausal women. The deterioration of bone status in women after cessation of hormonal activity of their ovaries (as compared to BMC of agematched females whose bones are still exposed to endogenous estrogens) is especially marked within the trabecular bone mineral content.

The results of the two-way ANOVA concerning the statistical significance of 


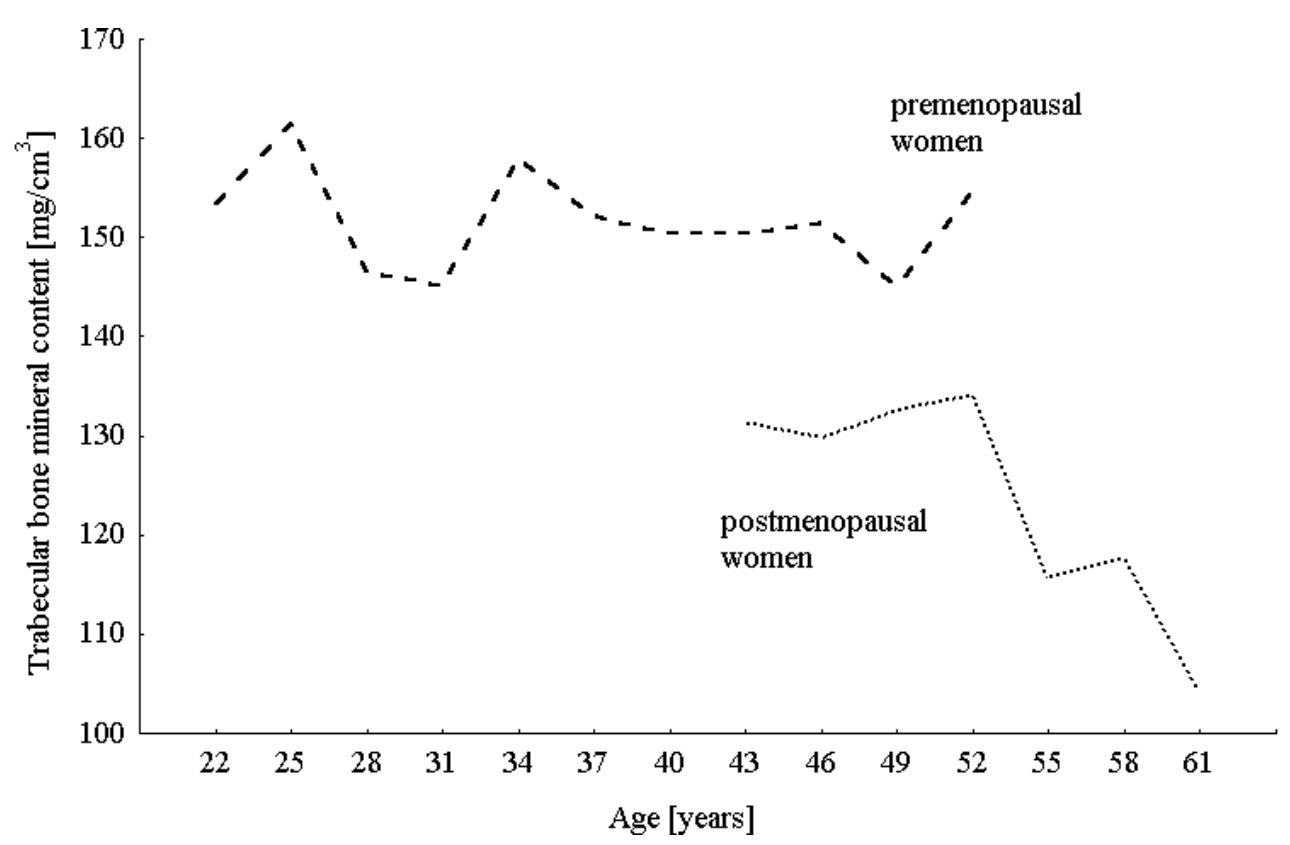

Fig. 1. Age-related differences in trabecular bone mineral content of pre- and postmenopausal Polish women.

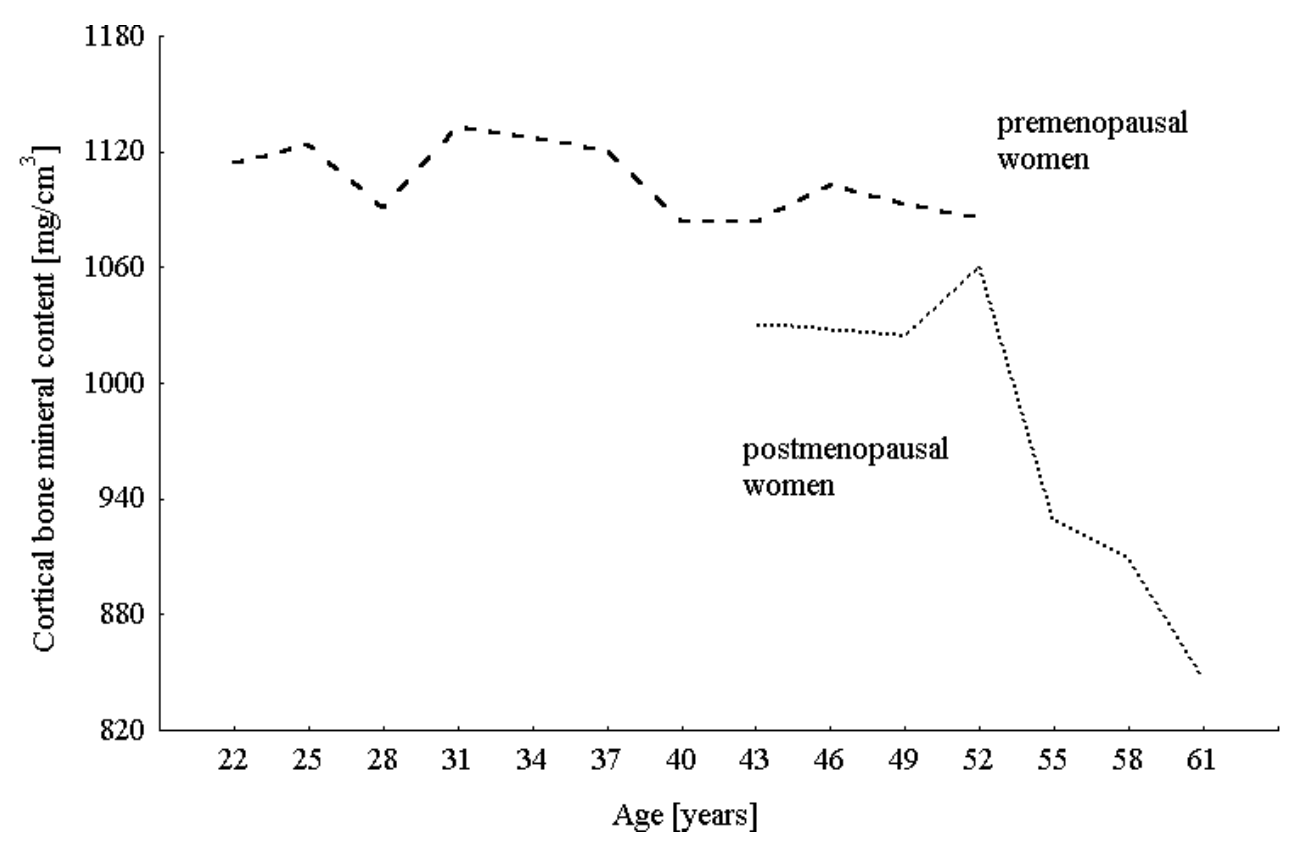

Fig. 2. Age-related differences in cortical bone mineral content of pre- and postmenopausal Polish women. 


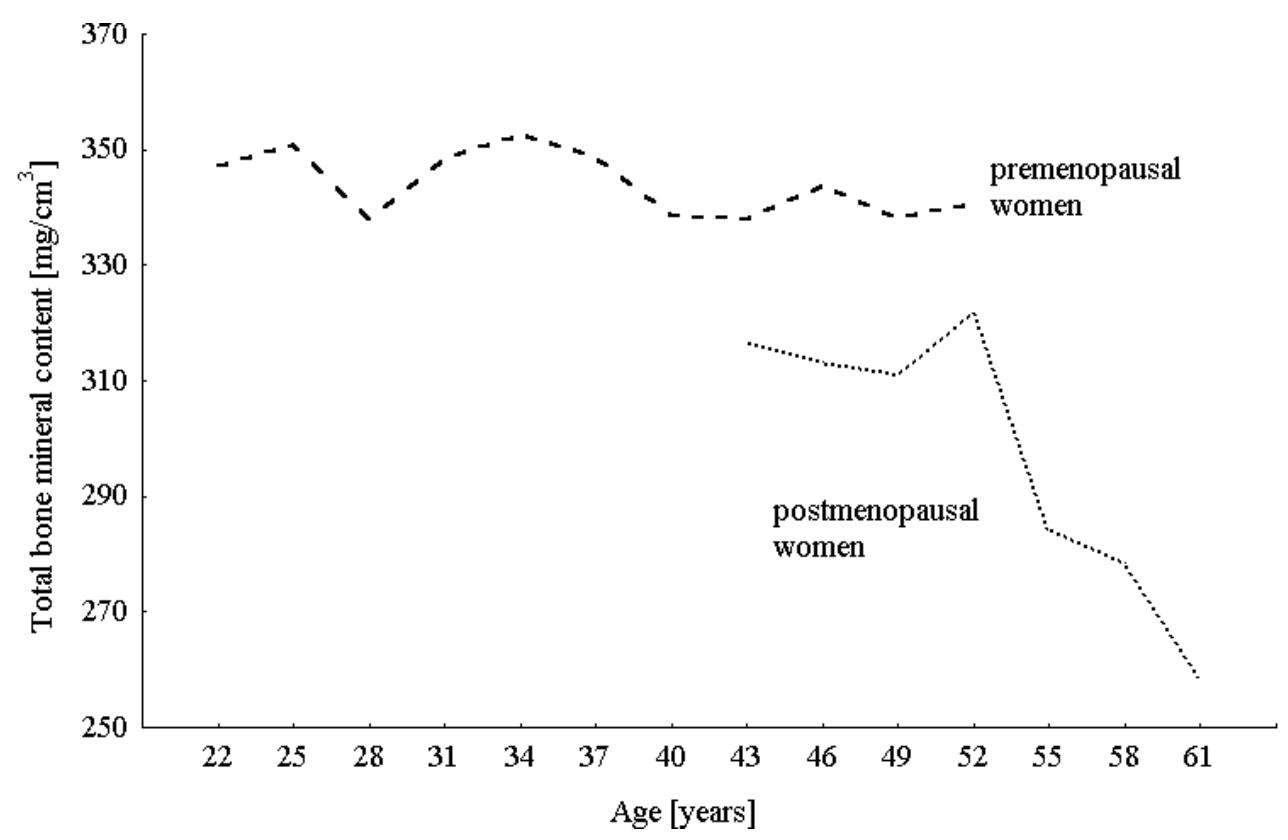

Fig. 3. Age-related differences in total bone mineral content of pre- and postmenopausal Polish women.

differences in particular BMC between two groups of women (pre- versus postmenopausal) are presented in Table 1. These data clearly show that the occurrence of menopause significantly speeds up the decline in female BMC and the impact of menopausal hormonal alterations is much stronger than that of chronological age. This phenomenon is most manifestly observed within trabecular BMC, but is also distinctly seen within both cortical and total bone mineral content of healthy Polish women.

The results of the two-way ANOVA concerning the differences in particular BMC between two groups of women (pre- versus postmenopausal) with regard to their menarcheal age are shown

Table 1. The results of the two-way ANOVA concerning the differences in BMC of healthy Polish women (factors: age and menopausal status)

\begin{tabular}{lcccccc}
\hline & \multicolumn{2}{c}{ Trabecular BMC } & \multicolumn{2}{c}{ Cortical BMC } & \multicolumn{2}{c}{ Total BMC } \\
\cline { 2 - 7 } & $F$ & $p$ & $F$ & $p$ & $F$ & $p$ \\
\hline Age & 0.910 & 0.704 & 0.498 & 0.763 & 0.712 & 0.601 \\
Pre- versus post-menopausal women & $\mathbf{1 6 . 1 2 1}$ & $\mathbf{0 . 0 0 0 1}$ & $\mathbf{5 . 7 2 8}$ & $\mathbf{0 . 0 1 6}$ & $\mathbf{1 1 . 4 7 7}$ & $\mathbf{0 . 0 0 0 8}$ \\
Interactions & 1.503 & 0.158 & 1.401 & 0.217 & 1.793 & 0.178 \\
\hline
\end{tabular}

Significant differences are indicated in bold. 
Table 2. The results of the two-way ANOVA concerning the differences in BMC of premenopausal Polish women (factors: chronological and menarcheal age)

\begin{tabular}{lcccccc}
\hline & \multicolumn{2}{c}{ Trabecular BMC } & \multicolumn{2}{c}{ Cortical BMC } & \multicolumn{2}{c}{ Total BMC } \\
\cline { 2 - 7 } & $F$ & $p$ & $F$ & $p$ & $F$ & $p$ \\
\hline Age & 0.613 & 0.690 & 0.692 & 0.630 & 0.684 & 0.636 \\
Menarcheal age & $\mathbf{7 . 7 6 7}$ & $\mathbf{0 . 0 0 0 5}$ & $\mathbf{3 . 6 2 8}$ & $\mathbf{0 . 0 2 7}$ & $\mathbf{5 . 7 5 9}$ & $\mathbf{0 . 0 0 3}$ \\
Interactions & 0.704 & 0.721 & 0.988 & 0.452 & 0.904 & 0.530 \\
\hline
\end{tabular}

Significant differences are indicated in bold.

Table 3. The results of the two-way ANOVA concerning the differences in BMC of postmenopausal Polish women (factors: chronological and menarcheal age)

\begin{tabular}{lcccccc}
\hline & \multicolumn{2}{c}{ Trabecular BMC } & \multicolumn{2}{c}{ Cortical BMC } & \multicolumn{2}{c}{ Total BMC } \\
\cline { 2 - 7 } & $F$ & $p$ & $F$ & $p$ & $F$ & $p$ \\
\hline Age & 2.361 & 0.082 & $\mathbf{4 . 7 6 8}$ & $\mathbf{0 . 0 0 2}$ & $\mathbf{5 . 5 0 6}$ & $\mathbf{0 . 0 0 1}$ \\
Menarcheal age & 1.130 & 0.335 & 1.281 & 0.295 & 1.751 & 0.181 \\
Interactions & 0.517 & 0.759 & 1.085 & 0.376 & 1.341 & 0.265 \\
\hline
\end{tabular}

Significant differences are indicated in bold.

in Tables 2 and 3. Among postmenopausal women, age at menarche is not significant for their BMC. Contrariwise, premenopausal women of earlier menarche reveal better bone status compared to premenopausal subjects of average or delayed menarche. This phenomenon is most marked within trabecular $\mathrm{BMC}$, but it is also significant within cortical and total bone mineral content of examined subjects. Simultaneously, in premenopausal subjects there is no relationship between age and bone density. Paradoxically, among postmenopausal women the detrimental effect of aging on bone is revealed within cortical and total BMC (but not within trabecular BMC).
Figures 4, 5 and 6 present the mean values of trabecular, cortical and total BMC of healthy premenopausal Polish women, evaluated in particular 6-year age categories in regard to their menarcheal age.

The influences of both the total number of reproductive years and the period passed after menopause on BMC of postmenopausal women were tested using a two-way ANOVA. The results are presented in Table 4. The total number of reproductive years is not significant for bone status in this group of examined subjects, whereas the longer period after menopause has a detrimental effect on both trabecular, cortical and total BMC. 


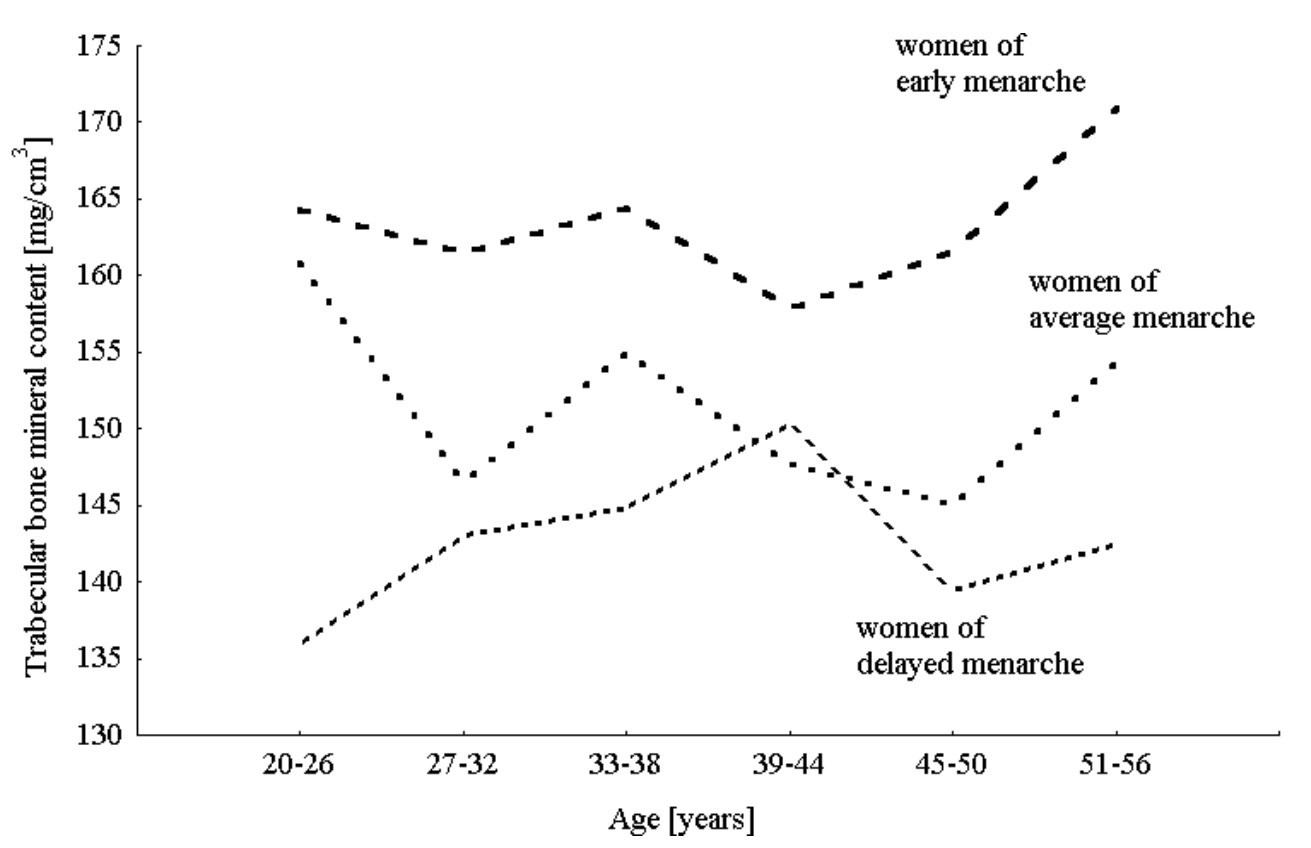

Fig. 4. Age-related differences in trabecular BMC of premenopausal healthy Polish women with regard to their menarcheal age.

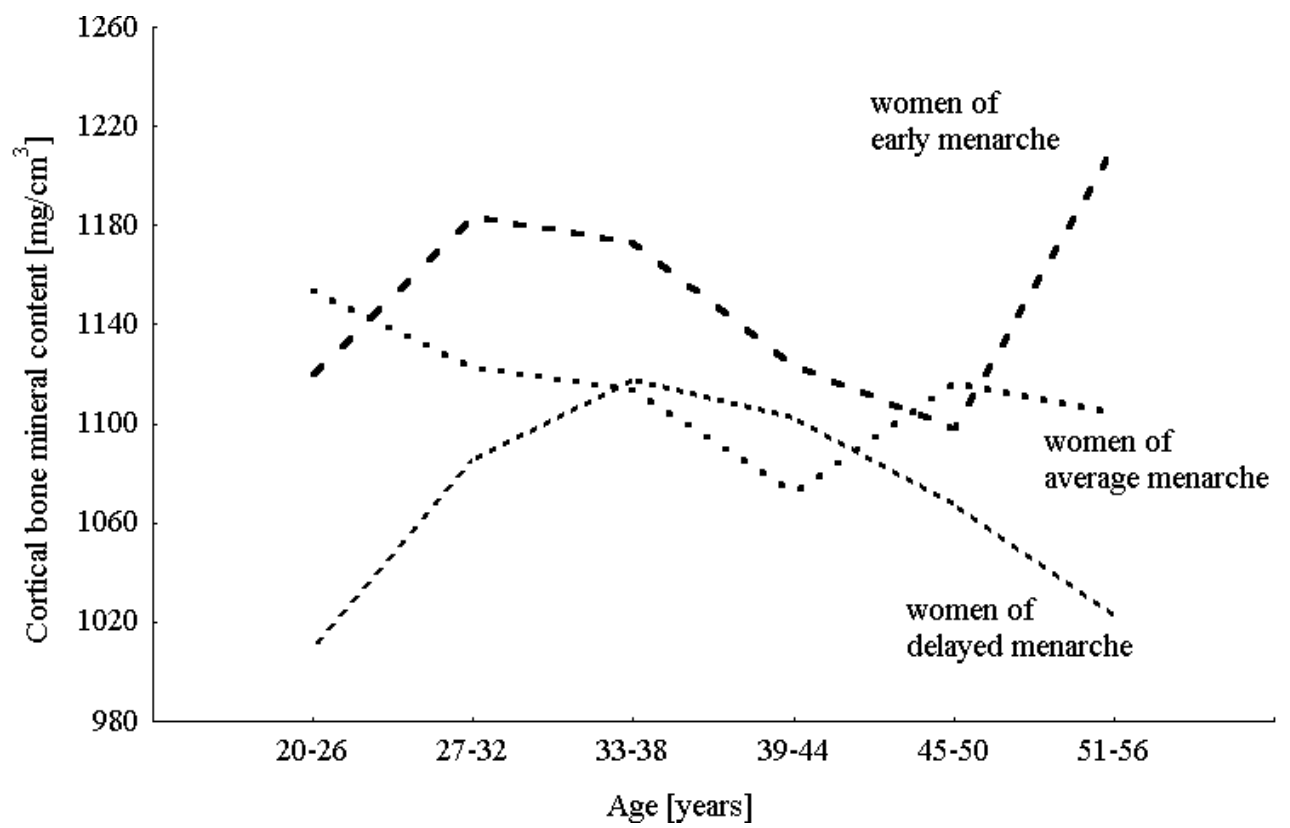

Fig. 5. Age-related differences in cortical BMC of premenopausal healthy Polish women with regard to their menarcheal age. 


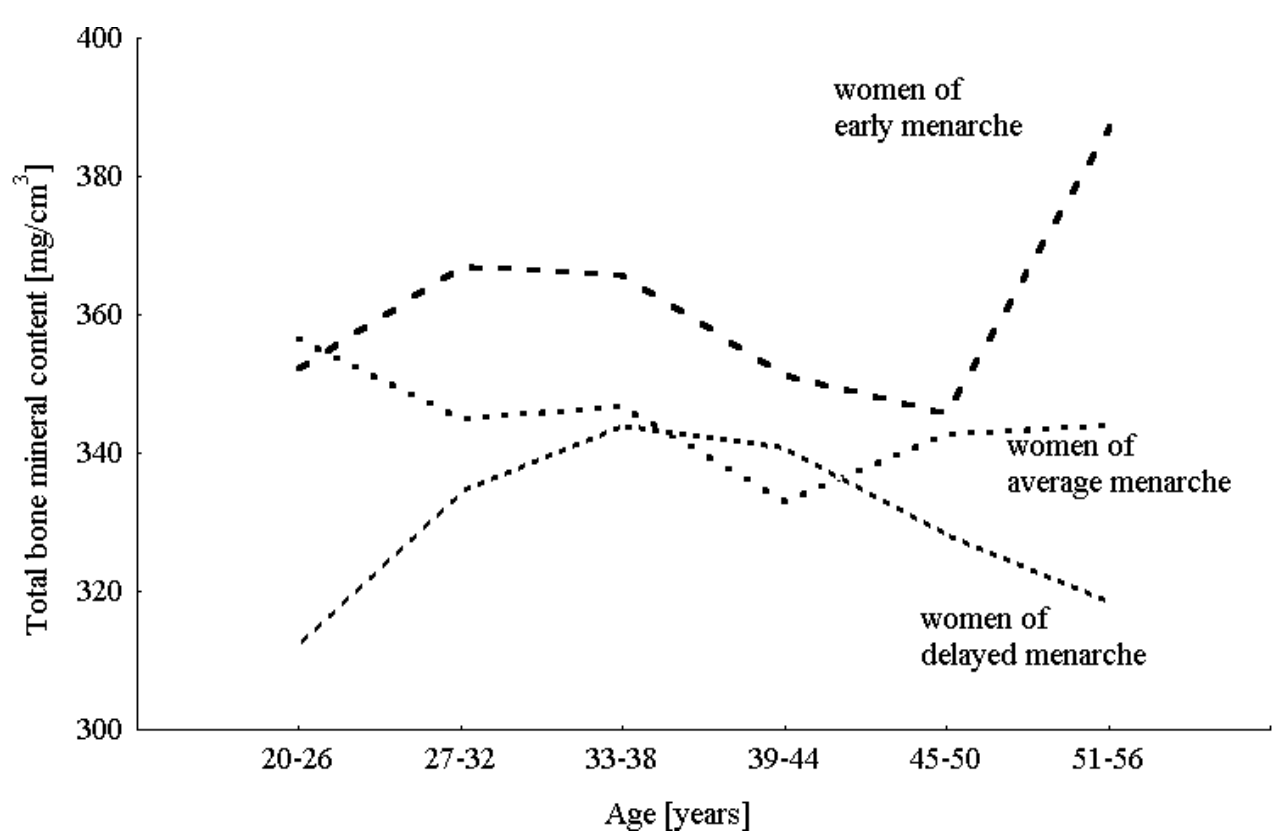

Fig. 6. Age-related differences in total BMC of premenopausal healthy Polish women with regard to their menarcheal age.

Table 4. The results of the two-way ANOVA concerning the differences in BMC of postmenopausal Polish women (factors: reproductive period and period after menopause)

\begin{tabular}{lcccccc}
\hline & \multicolumn{2}{c}{ Trabecular BMC } & \multicolumn{2}{c}{ Cortical BMC } & \multicolumn{2}{c}{ Total BMC } \\
\cline { 2 - 7 } & $F$ & $p$ & $F$ & $p$ & $F$ & $p$ \\
\hline Reproductive period & 0.332 & 0.695 & 0.750 & 0.488 & 1.012 & 0.300 \\
Period after menopause & $\mathbf{5 . 0 0 4}$ & $\mathbf{0 . 0 0 5}$ & $\mathbf{9 . 1 1 3}$ & $\mathbf{0 . 0 0 0 7}$ & $\mathbf{1 0 . 8 0 1}$ & $\mathbf{0 . 0 0 0 0}$ \\
Interactions & 0.630 & 0.509 & 1.499 & 0.208 & 1.538 & 0.206 \\
\hline
\end{tabular}

Significant differences are indicated in bold.

\section{Discussion}

Osteoporosis is a disease that results in fragility fractures and leads to increased mortality and morbidity, especially among elderly women, with huge financial implications for government budgets world-wide. The determinants of fractures are skeletal factors (the acquisition of peak bone mass during human growth, the rate of bone loss with age) and extra-skeletal factors which include the trauma itself and the response to that trauma [WALKER-BONE et al. 1998].

Bone mineral density is a complex characteristic that is affected, among the others, by several factors resulting from 
reproductive history. Its development is a function of the acquisition of peak bone mass around the age of 25-30 (the timing of menarche seems to be important in this process), the maintenance of proper bone density due to physiologic hormonal activity of ovaries between menarche and menopause, and the rate of bone loss in the course of normal female aging. Surprisingly, there are not many studies concerning the influence of menopause on female bone status. KRITZ-SILVERSTEIN and BARRETTCONNOR [1993] found among 555 postmenopausal women aged 60-89 that age at menopause was significantly positively correlated with BMD at ultradistal wrist, midshaft radius, lumbar spine and hip, even after adjustment for covariates. According to Willing both age and age at menopause were strong predictors of BMD (measured at femoral neck using dual photon X-ray absorptiometry) in the local population of 134 postmenopausal white Iowan women aged 57-81 [WILLING et al. 1997].

In Eastern Europe only one pilot study has thus far been published concerning the individual variation in pQCTassessed BMC of adult women. This was carried out in Poland among a total sample of 97 females aged 25-70 years with only few subjects from peri- and postmenopausal age categories [TAŁAJKO et al. 1995]. There are no analogous data from other countries of this part of Europe. In our study, the chronological age (as an equivalent of senile processes) appeared to have no significance for bone density of healthy Polish women. Simultaneously, the fact of menopause implicated the dramatic deterioration of trabecular, cortical and total bone mineral content of examined females. Our observation not only confirms the effect of menopause on female bone density revealed by other authors [HANSEN et al. 1991, SOWERS et al. 1992, IKI et al. 1996, MATKOVIC 1996], but additionally it suggests that the generally known distinct decline in mean BMC values between 40 and 60 years of age in particular age categories is a reflection of the rapid increase of frequency of postmenopausal women rather than an effect of aging as such. The greatest impact of menopause on female bone is found within trabecular $\mathrm{BMC}$, as that part of bone structure is presumed to be the most susceptible to any hormonal influences. Such marked influence of menopausal hormonal alterations on female bone tissue suggests that the subsequent statistical analyses concerning the impact of other factors of reproductive history should be evaluated separately in 2 groups: pre- and postmenopausal women.

The relationships between BMC and menarcheal status are different with regard to the skeletal site where bone mineral density is measured. YOUNG et al. [1995] showed in 215 females aged 10-26 that areal bone density at lumbar spine and total body BMC (measured using dual energy X-ray absorptiometry) were independently associated with menarcheal status of examined subjects. Simultaneously, no differences between pre- and postmenarche individuals after adjustment for confounding factors in areal bone density at femoral neck, Ward's triangle and total hip were found [YOUNG et al. 1995]. It is noteworthy that relationships between bone density and menarcheal age seem to be modified by the genotype variation of particular genes whose products are involved in 
bone metabolism [KITAGAWA et al. 1998]. The authors found among Japanese girls aged 18-19 that BMD at the distal radius was significantly dependent on earlier onset of menarche in the population with genotype Aa of vitamin $\mathrm{D}$ receptor gene, but not in the population with genotype aa [KITAGAWA et al. 1998]. Furthermore, results of previous studies on the influence of menarcheal age on bone density seem to be conflicting; some reveal beneficial, others - detrimental effects on BMC, and most papers focus on relationships between menarcheal age and BMD only in girls and premenopausal women [MCKAY et al. 1998, BONOFIGLIO et al. 1999, OSEI-HYIAMAN et al. 1998].

According to Bonofiglio, radial BMD was higher in postmenarcheal girls compared to premenarcheal ones of the same age [BONOFIGLIO et al. 1999]. In the study of ARMAMENTO-VILLAREAL et al. [1992] in 63 premenopausal women aged $19-40$, the subjects with lower vertebral bone density had higher age at menarche [OSEI-HYIAMAN et al. 1998]. Conversely, a longitudinal study of McKay demonstrated the association between the age at PBMCV (peak bone mass content velocity) and the age at menarche and confirmed the greater PBMCV in earlier, as compared with later, maturing girls [MCKAY et al. 1998].

On the basis of the results of the twoway ANOVA we have revealed that in premenopausal women the influence of menarcheal age on both trabecular, cortical and total BMC has persisted. It is obvious that the greatest effect of menarcheal age is seen within trabecular compartment.

Thus far, there is only one published study on the influence of menarcheal age on bone density in postmenopausal women. Fox examined 2,230 white women aged 65 and older, and found that subjects who began menstruation at the age of 9 had $6,3 \%$ higher BMD than those women who began menses at the age of 16 [FOX et al. 1993]. In our study the menarcheal age is not significantly related to any BMC at the distal radius of postmenopausal healthy Polish women. This finding probably results from the fact that menopausal hormonal alterations have large detrimental effects on female bone, that after the cessation of hormonal activity by ovaries the past menarcheal history is no longer of importance for bone status in later female life.

The relationships between BMC and the total number of reproductive years in postmenopausal subjects seem to be obvious, but in fact are not so evident. In the study of Fox et al. [1993], each decade of menstruation was associated with a $2 \%$ increase of distal radius BMD. KRITZ-SILVERSTEIN and BARRETT-CONNOR [1993] examined relationships between number of reproductive years (defined as age at menopause minus age at menarche) and BMD measured at ultradistal wrist, midshaft radius, lumbar spine and hip in 555 postmenopausal women. The authors reported positive associations between the number of reproductive years and BMD at every site; moreover the total number of reproductive years explained more of the variance in BMD than did either age at menarche or age at menopause [KRITZ-SILVERSTEIN and BARRETT-CONNOR 1993].

Osei-Hyiaman measured BMD of the right second metacarpal bone in 1,035 naturally postmenopausal Japanese women aged 40-70. Subjects with late 
menopause were at decreased risk for low BMD, even after adjustment for additional covariates. Postmenopausal women with more reproductive years (calculated as age at menopause minus age at menarche) were at decreased risk of osteoporosis after adjustment for age and potentially confounding factors, and might be less prone to osteoporosis [OSEI-HYIAMAN et al. 1998]. Our results of the two-way ANOVA concerning the influences of both the number of reproductive years, and the period after menopause on mean values of BMC of postmenopausal women are not in accordance with previous studies. The number of reproductive years is not an independent predictor of better bone status after menopause, whereas the longer period after menopause appears to reduce significantly both cortical and total BMC.

In the context of this study, in making inferences about a pattern of agechanges in BMC, one important consideration should be kept in mind. Our material comprises only healthy, occupational active women individuals. Such material, therefore, could have been subject to selective dropout. It is possible that persons with inferior bone status in our sample are under-represented in older age categories because many of them have already left the active work force. In other words, older subjects present in our sample may tend to be healthier than all their age-mates in the general population, and this bias may be expected to increase when moving up the age scale. It is obvious that a better general biological condition (the better psychosomatic health) of any subject results in delay of the normal ageing processes. Thus it can be pre- sumed that the real rate of decline and the effect of ageing on bone tissue in elderly women in the general population is at least as great as that revealed in our study.

\section{References}

Albright F., 1941, Postmenopausal osteoporosis, J. Am. Med. Assoc., 116, 2465-2473

ARMAMENTO-VILlareal R., D.T. Villareal, L.V. Avioli, R. Civitelli, 1992, Estrogen status and heredity are major determinants of premenopausal bone mass, J. Clin. Invest., 90, 2464-2471

Augat P., T. Fuerst, H.K. Genant 1998, Quantitative bone mineral assessment at the forearm: A review, Osteoporos. Int., 8, 299-310

Bonofiglio D., M. Maggiolini, S. Marsico, A. Giorno, S. Catalano, S. Aquila, S. Ando, 1999, Critical years and stages of puberty for radial bone mass apposition during adolescence, Horm. Metab. Res., 31, 478-482

Fox K.M., J. Magaziner, R. Sherwin, J.C. Scott, C.C. Plato, M. Nevitt, S. Cummings, 1993, Reproductive correlates of bone mass in elderly women. Study of Osteoporotic Fractures Research Group, J. Bone Miner. Res., 8, 901-908

GÄrdsell P., O. JohNEll, B. Nilsson, B. Gullberg, 1993, Predicting various fragility fractures in women by forearm bone densitometry, Calcif. Tissue Int., 52, 348-353

Gordon C.L., C.E. WebBer, J.D. AdAchi, N. CHRISTOFORON, 1996, In vivo assessment of trabecular bone structure at the distal radius from high-resolution computed tomography images, Phys. Med. Biol., 41, 495-508

Grampr S., P. LANG, M. Jergas, C.C. GlÜER, A. Mathur, K. EngelKe, H.K. Genant, 1995, Assessment of the skeletal status by peripheral quantitative computed tomography of the forearm: Short-term precision in vivo and comparisons to dual X-ray absorptiometry, J. Bone Miner. Res., 10, 1566-1576

GronKIEWICZ L., 2001, Social-class differences in Poland pronounced in stature, but absent in gene frequencies, Przegląd Antropol.Anthropol. Rev., 64, 73-79 
HANSEN M.A., K. OvergaARD, B. J. RÜs, C. CHRISTIANSEN, 1991, Role of peak bone mass and bone loss in postmenopausal osteoporosis: 12 year study, Br. Med. J., 303, 961-964

Hasegawa Y., K. Kushida, K. Yamazaki, T. INAUE, 1997, Volumetric bone mineral density using peripheral quantitative computed tomography in Japanese women, Osteoporos. Int., 7, 195-199

IKI M., Y. DOHI, H. Nishino, E. KaJita, Y. KusAKA, C. Tsuchida, K. YамамотоK, Y. ISHII, 1996, Relative contributions of age and menopause to the vertebral bone density of healthy Japanese women, Bone, 18, 617-620

JOHNELL O., 1997, The socioeconomic burden of fractures: Today and in the 21 st century, Am. J. Med., 103, 20-26

Kitagawa I., Y. Kitagawa, Y. Kawase, T. NAGAYA, S. TOKUDOME, 1998, Advanced onset of menarche and higher bone mineral density depending on vitamin $D$ receptor gene polymorphism, Eur. J. Endocrinol., 139, 522-527

KRITZ-SILVERSTEIN D., E. BARRETT-CONNOR, 1993, Early menopause, number of reproductive years, and bone mineral density in postmenopausal women, Am. J. Public Health, 83, 983-988

Lippuner K., J. von Overbeck, R. Perrelet, H. BOSSHARD, P. JAEGER, 1997, Incidence and direct medical costs of hospitalizations due to osteoporotic fractures in Switzerland, Osteoporos. Int., 7, 414-425

Matkovic V., 1996, Nutrition, Genetics and Skeletal Development, J. Am. Coll. Nutr., 15, 556-569

Matkovic V., J.Z. Ilich, M. Skugor, N.E. BAdenhop, P. Goel, A. Clarimont, D. KLISOVIC, R.W. NAHHAS, J.D. LANDOLL, 1997, Leptin is inversely related to age at menarche in human females, J. Clin. Endocrinol. Metab., 82, 3239-3245

McKay H.A., D.A. Bailey, R.L. Mirwald, K.S. DAVISON, R.A. FAULKNER, 1998, Peak bone mineral accrual and age at menarche in adolescent girls: A 6-year longitudinal study, J. Pediatr., 133, 682-687

Osei-Hyiaman D., T. Satoshi, M. UeJi, T. Hideto, K. KANO, 1998, Timing of menopause, reproductive years, and bone mineral density: A cross-sectional study of postmenopausal Japanese women, Am. J. Epidemiol., 148, 1055-1061

Sowers M.R., M.K. Clark, B. Hollis, R.B. Wallace, M. JanNausCh, 1992, Radial bone mineral density in pre- and perimenopausal women: A prospective study of rates and risk factors for loss, J. Bone Mineral. Res., 7, 647-657

TAŁAJKo A., R.S. LORENC, S. RADOWICKI, 1995, Ilościowa tomografia komputerowa obwodowych czéści ciała (pQCT) - wyniki pomiarów u zdrowych kobiet $w$ populacji polskiej, Pol. Tyg. Lek., 44, 24-26

The Weimar Initiative: Healthy Aging for Men, 1998, (Appendix), The Aging Male, 1, 7

WALKer-Bone K., D.M. ReID, C. COOPER, 1998, Is screening for osteoporosis worthwhile? $\mathrm{Br}$. Med. Bull., 54, 915-927

Willing M.C., J.C. TORnER, T.L. BuRns, E.T. Segar, J.R. Werner, 1997, Determinants of bone mineral density in postmenopausal white Iowans, J. Gerontol. A: Biol. Sci. Med. Sci., 52, 337-342

Young D., J.L. Hopper, C.A. Nowson, R.M. Green, A.J. Sherwin, B. KaymakCI, M. SMID, C.S. Guest, R.G. LARKINS, J.D. WARK, 1995, Determinants of bone mass in 10- to 26year-old females: A twin study, J. Bone Miner. Res., 10, 558-567

\section{Streszczenie}

Celem pracy były: (1) ocena, który czynnik, wiek kalendarzowy czy menopauza, ujawnia bardziej szkodliwy wpływ na stan mineralizacji kośćca (BMC) zdrowych kobiet; (2) oszacowanie wpływu innych czynników (wiek menarchy, ilość lat reprodukcji, ilość lat po menopauzie) na redukcję masy kostnej. Materiał stanowiła grupa 928 kobiet (715 przed i 213 po menopauzie), w wieku od 20 do 62 lat, zdrowych, czynnych zawodowo mieszkanek Wrocławia. Gęstość gąbczasta, korowa i całkowita oceniana była na przedramieniu ręki 
niedominującej metodą pQCT przy użyciu aparatu XCT Stratec 960. Badane kobiety podawały $\mathrm{w}$ ankiecie wiek chronologiczny, wiek menarchy i wiek menopauzy. Z tych danych obliczono liczbę lat reprodukcji i liczbę lat po menopauzie. Różnice pomiędzy poszczególnymi grupami testowano za pomocą dwuczynnikowej analizy wariancji ANOVA.

Uzyskane wyniki wskazuja, że menopauza silniej niż wiek chronologiczny obniża poziom BMC, w szczególności w części gąbczastej (tab. 1). Dlatego też w dalszej analizie wydzielono 2 grupy kobiet: przed i po menopauzie. Wcześniejsza menarcha miała istotny wpływ na BMC jedynie u kobiet przed menopauzą (tab. 2 i 3, rys. 4-6). Wśród kobiet po menopauzie na redukcję masy kostnej silniejszy wpływ miała liczba lat jakie upłynęły od menopauzy niż długość okresu reprodukcyjnego (tab. 4). Należy zauważyć, że wiek kalendarzowy istotnie wpływa na obniżenie masy kostnej tylko wśród kobiet po menopauzie (rys. 1-3). 